\title{
ANKLE-BRACHIAL INDEX AND LDL-RECEPTOR GENE IN ASYMPTOMATIC SEVERE HYPER- CHOLESTEROLEMIA
}

\author{
L. Vladimirova-Kitova \\ Clinic of Cardiology, \\ Medical University, Plovdiv, Bulgaria
}

\begin{abstract}
The issue with the different levels of ankle-brachial index, as screening for LDL-receptor defective gene in newly detected asymptomatic severe hypercholesterolemia is less studied, but quite interesting. There have not been any studies on ankle-brachial index in patients with severe hypercholesterolemia in Bulgaria. Aim: To examine the difference between patients with severe hypercholesterolemia, who are carriers and non-carriers of LDL-R defective gene, with respect to their structural (ankle-brachial index) characteristics of arterial wall. Methods and materials: 60 patients with documented severe hypercholesterolemia $>7.5$ $\mathrm{mmol} / \mathrm{l}$ satisfying the Simon-Broom criteria for clinically established and probable Familial Hypercholesterolemia were studied. All of the patients had a negative stress echocardiography and not known coronary artery disease. The laboratory used was the Clinical Laboratory at the Medical University Plovdiv. The total cholesterol and triglycerides were measured with enzyme-colorimetry and cholesterol in high density lipoprotein and cholesterol in low density lipoprotein with direct automatic analyses. Apolipoproteins were calculated by immunoturbodimetric method. The biochemical analyzer Konelab 60i was used in all the measurements. Results: According to whether there were or were not molecular defects, patients were assigned to two groups: carriers (11 patients, $18 \%$ ) and non-carriers (49 patients, $82 \%$ ). There was a statistically significant difference $(p<0.001)$ in the age distribution of patients, carriers and non-carriers of molecular defects. This conclusion was confirmed by the calculated mean age in both patient groups. The mean age of non-carriers was $48.20 \pm 0.47$ years, the mean age of carriers $-45.77 \pm 0.36$ years. There were no statistical differences in the sex distribution in the study sample (ч2 $=0.05 ; \mathrm{p}>0.05$ ). We found no statistically significant difference between non-carriers and carriers with respect to body mass index $(25.30 \pm 0.40$ vs $24.63 \pm 0.45$, respectively, $\mathrm{t}=0.50 ; \mathrm{p}>0.05$ ). There was not a statistically significant difference in levels of total cholesterol, triglycerides, HDL-cholesterol, LDL-cholesterol between carries $(p>0.05)$. The cholesterol $x$ years.score was significantly higher in the carries $(440.36 \pm 0.25 \mathrm{mmol}-\mathrm{y} / \mathrm{L})$,
\end{abstract}

than in the non-carries $(390.30 \pm 0.07 \mathrm{mmol}-\mathrm{y} / \mathrm{L})$. We found a significantly lower ABI in the carriers vs. non-carriers $(p<0.001)$ (Table 2). This significant difference was confirmed after adjustment for age and gender $(p<0.05)$ Conclusion: The major findings of the present study are that $\mathrm{ABI}$ is significantly lower in carriers of the LDL-R defective gene vs. non-carriers.

Key words: hypercholesterolemia, ankle-brachial index, peripheral vascular disease, low- density lipoprotein receptor, molecular biological analysis

\section{INTRODUCTION}

International recommendations for treatment of hypercholesterolemia stress the importance of diagnosis and treatment of asymptomatic individuals with high absolute cardiovascular risk. Individuals with marked hypercholesterolemia fall into this group as well. Familial hypercholesterolemia $(\mathrm{FH})$ can be due to different genetic defects in the LDL-R, which lead to impaired LDL clearance $[1,2]$. Mutations of the LDL-R-gene are characterized by a high genetic heterogeneity $[1,2]$. Nearly $80 \%$ of the population specific heterogeneity is due to point mutations along the LDL-R gene. This fact requires genetic scanning of all exons. Monogenetic hypercholesterolemia is more frequent, than it was thought before and it remains undiagnosed. On the other hand, the early diagnosis and the identification of the underlying genetic mutation are very important for risk and therapy. The different expression of the defect gene in LDL$\mathrm{R}$ mutation carriers as well as the presence of elevated LDL levels in non-mutation carriers makes diagnosis difficult. So far, there is no optimal diagnostic algorithm in clinical diagnosis FH.There are many possibilities of angiographic methods discussed to delimit the carriers vs.non-carriers of LDL-R defective gene. The ankle brachial pressure index is a good predictor of subsequent cardiovascular events, and improves on predictions by conventional risk factors alone [3-11]. It is simple and accurate and could be included in routine screening of cardiovascular status. The reference values were presented at TransAtlantic Intersociety Consensus Working Group in 2005: Normal is 0.9, mild PVD; 0.5-0.75, moderate PVD; less than 0.5 severe PVD. More than 
1.3 - falsely elevated (non-compensated vessels) There have small studies on ankle-brachial index in patients with severe hypercholesterolemia in Bulgaria [12-21]. There are not so many facts for this method of screening of patients with this molecular defect-point mutations of LDL-R gene.

\section{PATIENTS AND METHODS}

We included 60 (age over 16 years) patients with primary hypercholesterolemia, which met the Simon-Broome register criteria [22] [1. Total cholesterol level above $7.5 \mathrm{mmol} /$ 1 in people over 16 years of age. 2. Tendon xanthomata in first or second degree relatives. 3. A myocardial infarction before age 60 in first degree relatives and before age 50 in second degree relatives. 4 . Total cholesterol above $7.5 \mathrm{mmol} /$ 1 in first or second degree relatives]. A diagnosis of definite FH requires meeting criteria 1 and 2. A diagnosis of possible FH requires meeting criteria 1 and 3 or 1 and 4. The exclusion criteria's were all know conditions beyond the hypercholesterolemia, which connected with development of endothelial dysfunction.

Prior to the study procedures a written informed consent was obtained from hypercholesterolemic patients. The procedures used in this study were approved by the Ethics Committee at Medical University of Plovdiv.

All study subjects were assessed for family history of early-onset coronary artery disease, clinical history, medication use, anthropometric characteristics, cardiovascular risk factors and tendon xanthomas. All the patients are asymptomatic and they had not taken statins up to medical examination.

Laboratory tests were performed at the Central Clinical Laboratory of St George University Hospital, Plovdiv. The biochemical parameters of blood glucose, total cholesterol, triglycerides, high density lipoprotein cholesterol, urea, creatinine, and uric acid were measured using a biochemical analyzer Konelab 60i (Thermo Electron Co, USA). Determination of LDL-cholesterol was performed using a direct analysis and reagents from Thermo Electron Co KonelabTM (Finland). The "cholesterol-years" score is an estimate of the lifelong total vascular exposure to the profound hypercholesterolemia in these patients. This cholesterol-years score was calculated as follows - the total cholesterol concentration (in $\mathrm{mmol} / \mathrm{L}$ ) of each patient at the time of original diagnosis was multiplied by the age of the patient at diagnosis.

Molecular biological analysis. The present study included 120 DNA samples of FH patients of both genders. Samples of high-molecular DNA isolated from nuclear blood cells were used as material for the genetic analysis. The blood samples were withdrawn 30 min to 1 hour after meals in plastic tubes with EDTA anticoagulant. They were stored at $+4^{\circ} \mathrm{C}$ for 48 hours. The technique included several stages: 1. Isolation of DNA; 2. Amplification of a specific target of DNA fragment using polymerase chain reaction; 3 . A single strand conformation polymorphism SSCP analysis; 4. Direct sequencing. The R3500Q-mutation in the Apo-B gene was sought first [21]. LDL-R gene mutation and polymorphism (and the promoter region), , were then identified using denaturing gradient gel electrophoresis [22] and DNA sequecimg of the abnormal exon. When these analyses were negative, DNA was subjected to long-range polymerase chain reaction (PCR).

Measuring of ABI was done by 7,5 $\mathrm{MHz}$ Hewlett Packard SONOS 2500 transducer and sphygmomanometer. Systolic arterial pressure is measured of both hands is measured by blood stream in fossa decubitalis. Measurment of systolic arterial pressure is the same for lower limbs- by Doppler effect of blood stream in a.tibialis posterior and a.dorsalis pedis. The higher values of SAP of both brachial arteries are taken,respectively these of the arteries of lower limbs.ABI is determined one by one for the lower limbs as correlation between the higher SAP of lower to upper limbs. The lower index between left and right side is taken.There were six measurements performed on every patient.Intima media complex of carotid artery was measured by the same transducer. The dimensions of both carotic arteries (right and left) were taken in the distalic $10 \mathrm{~mm}$ of a.carotis communis.Automatic measurement of carotic echograms was done by MedicaSoft.IMT.Lab automatic programme.The higher demarcation echografic line is defined as "leading fringe"(border intima-media) while the underlying line is named " far fringe". Tthe leading line is independent from gain tuning therefore it is the main line of automatic gauging.

We analyzed the reproducibility of the automatic measurement of ABI as did 5 times measurements of 30 patients. The distribution of these parameters were normal, which allowed us to calculate the coefficient of reproducibility of the Spearman - Brown and coefficient of repeatability. The results show that ABI $95 \%$ of cases two measurements will differ by less than 0.2 .

Statistical analysis was carried out using the SPSS v.14.0 statistical software (SPSS Inc. Chicago, III). Results were expressed as the mean \pm standard error (SEM). $\mathrm{P}<0.05$ was used as a level of significance of the null hypothesis. We studied the distribution of all continuous data by applying a normality test on the distribution (one-sample KolmogorovSmirnov test). Variation analysis, Student's t-criterion and analysis of covariance (ANCOVA) were used in the statistical analysis

\section{RESULTS}

According to whether there were or were not molecular defects, patients were assigned to two groups: carriers (11 patients, $18 \%$ ) and non-carriers (49 patients, $82 \%$ ).

\section{and anthropometric parameters \\ 1. Characteristics of the studied population - age, sex}

There was a statistically significant difference $(\mathrm{p}<$ $0.001)$ in the age distribution of patients, carriers and non- 
carriers of molecular defects. This conclusion was confirmed by the calculated mean age in both patient groups. The mean age of non-carriers was $48.20 \pm 0.47$ years, the mean age of carriers $-45.77 \pm 0.36$ years. There were no statistical differences in the sex distribution in the study sample (ч2 = $0.05 ; p>0.05$ ). We found no statistically significant difference between non-carriers and carriers with respect to body mass index ( $25.30 \pm 0.40$ vs $24.63 \pm 0.45$, respectively, $\mathrm{t}=0.50 ; \mathrm{p}>$ $0.05)$.

\section{Molecular biological analysis}

The most common family defect in Apo-B (caused by a substitution mutation at nucleotide position 10780 , which results in replacement of Arg in the defected polypeptide chain by Gln at position 3500) and no mutation of this type was found in the studied population, in patients with total cholesterol above $7.0 \mathrm{mmol} / \mathrm{l}$. The second stage included testing for spot mutations in the LDL-R gene. We screened all 18 exons of the LDL-R gene (apart from the recommended analysis of exons 6, 4 and 9) (Table 1.) [3,5]. According to whether there were or were not molecular defects, patients were assigned to two groups: carriers (11 patients, $18 \%$ ) and non-carriers (49 patients, $82 \%$ ).

Table 1. Molecular analysis of exons 1 through 18

\begin{tabular}{|l|c|c|c|c|c|c|c|c|c|c|c|c|c|c|c|c|c|c|c|}
\hline Exons & 1 & 2 & 3 & $4 \mathrm{a}$ & $4 \mathrm{~b}$ & 5 & 6 & 7 & 8 & 9 & 10 & 11 & 12 & 13 & 14 & 15 & 16 & 17 & 18 \\
\hline Knownmutations & 0 & 0 & 0 & 0 & 3 & 0 & 3 & 0 & 0 & 4 & 0 & 1 & 0 & 0 & 0 & 0 & 0 & 0 & 0 \\
\hline
\end{tabular}

\section{Lipid profile in the examined groups}

Total cholesterol and LDL levels were higher in carriers (total cholesterol-9.77 $\pm 0.49 \mathrm{mmol} / \mathrm{l}$; LDL-C-7.66 \pm $0.03 \mathrm{mmol} / \mathrm{l}$ ) compared to non-carriers (total cholesterol-8.33 $\pm 0.11 \mathrm{mmol} / \mathrm{l} ;$ LDL-C $-6.55 \pm 1.77 \mathrm{mmol} / \mathrm{l})$, but the difference between them did not reach statistical significance. Lower HDL-cholesterol levels were found in carriers (HDL-0.90 \pm $0.03 \mathrm{mmol} / \mathrm{l}$ ) compared to non-carriers (HDL-1.03 \pm 0.20 $\mathrm{mmol} / \mathrm{l}$ ), the difference also not reaching statistical significance. There was not a statistically significant difference in level of triglycerides between carries $(1.45 \pm$ $0.40 \mathrm{mmol} / \mathrm{l})$, and non-carriers $(1.40 \pm 0.30 \mathrm{mmol} / \mathrm{l})(\mathrm{p}>0.05)$. The cholesterol $x$ years.score was significantly higher in the carries $(440.36 \pm 0.25 \mathrm{mmol}-\mathrm{y} / \mathrm{L})$, than in the non-carries $(390.30 \pm 0.07 \mathrm{mmol}-\mathrm{y} / \mathrm{L})$.

\section{Ankle-brachial index in carriers and non-carriers}

We found a significantly lower ABI in the carriers vs. non-carriers $(\mathrm{p}<0.001)$ (Table 2.). This significant difference was confirmed after adjustment for age and gender $(p<0.05)$

Table 2. Ankle-brachial index in the examined groups

\begin{tabular}{|l|c|c|c|c|c|}
\hline & & $\begin{array}{c}\text { No age and gender } \\
\text { adjustment }\end{array}$ & & $\begin{array}{c}\text { Age and gender } \\
\text { adjustment }\end{array}$ & \\
\cline { 2 - 5 } & $\mathbf{N}$ & $\mathrm{x} \pm \mathrm{Sx}$ & $\mathrm{p}$ & $\mathrm{x} \pm \mathrm{Sx}$ & $\mathrm{p}$ \\
\hline ABI & & & & & \\
Non carriers & 49 & $1.16 \pm 0.13$ & $<0.001$ & $1.17 \pm 0.02$ & $<0.05$ \\
Carriers & 11 & $0.98 \pm 0.08$ & & $1.06 \pm 0.02$ & \\
\hline
\end{tabular}

\section{DISCUSSION}

The major findings of the present study are that $\mathrm{ABI}$ is significantly lower in carriers of the LDL-R defective gene vs. non-carriers. This point is confirmed after standatization by sex and age-this difference is associated by presence of point mutations or polymorphism of LDL-receptor.Despite of this fact the lower levels of ABI are in borderline for this index about cardiovascular risk profile.Therefore reference values of ABI by patients with evidenced family hypercholesterolemia do not except molecular defect of the LDL-R gene.Thaking this in part, ABI must be a factor in the diagnostic risk algorhythm by patients with suspected family hypercholesterolemia as lower it is higher is the possibility of presence of molecular defect of the LDL-R gene.ABI should be use as additional marker in evaluation of cardiovascular risk by asymptomatic patients with genetic predisposition of family hypercholesterolemia.

\section{CONCLUSION}

The major findings of the present study are that $\mathrm{ABI}$ is significantly lower in carriers of the LDL-R defective gene vs. non-carriers. Lower levels of ABi are in the reference lines for this index concerning cardiovascular risk profil.This fact shows that the referent values of ABI by patients with family hypercholesterolemia do not discount the possibility of molecular defect of the LDL-R gene. 


\section{REFERENCES:}

1.Lusis AJ, Mar R, Pajukanta P. Genetics of atherosclerosis. Annu Rev Genomics Hum Genet. 2004; 5:189-218 [CrossRef] [PubMed]

2. Marks D, Thorogood M, Neil HA, Humphries SE. A review on the diagnosis, natural history and treatment of familial hypercholesterolemia. Atherosclerosis 2003; May;168(1):1-14. [CrossRef] [PubMed]

3. Rader DJ. Noninvasive Procedures for Subclinical Atherosclerosis Risk Assessment. Am J Med, 1999 Aug 23;107(2A):25S-27S. [PubMed]

4. Hooi JD, Stoffers HE, Kester AD, Kester AD, van Ree JW, Knottnerus JA. Peripheral arterial occlusive disease: prognostic value of signs, symptoms, and the ankle-brachial pressure index. Med Decis Making. 2002 Apr;22(2):99107. [CrossRef] [PubMed]

5. Management of peripheral arterial disease (PAD). TransAtlantic InterSociety Consensus (TASC). Int Angiol. 2000 Mar;19(Suppl 1):I-XXIV, 1-304. [PubMed]

6. Doobay AV, Anand SS. Sensitivity and Specificity of the Ankle-Brachial Index to Predict Future Cardiovascular Outcomes. A Systematic Review. Arterioscler Thromb Vasc Biol. 2005 Jul;25(7):1463-9. Epub. May 2005. [CrossRef] [PubMed]

7. Duprez D. HOPE brings hope for the use of the ankle-brachial index as cardiovascular risk marker. Eur Heart J. 2004 Jan;25(1):1-2. [CrossRef] [PubMed]

8. Sacks D, Bakal CW, Beatty PT, Becker GJ, Cardella JF, Raabe RD, et al. Position statement of the use of the ankle-brachial index in the evaluation of patients with peripheral vascular disease: a consensus statement developed by the standards division of the Society of Cardiovascular \& Interventional Radio-

logy. J Vasc Interv Radiol. 2002 Apr;13(4):353. [CrossRef] [PubMed]
9. Zheng ZJ, Sharret AR, Chambless LE, Rosamond WD, Nieto FJ, Sheps DS, et al. Associations of ankle-brachial index with clinical coronary heart disease, stroke and preclinical carotid and popliteal atherosclerosis:The atherosclerosis risk in communites (ARIC) study. Atherosclerosis 1997 May; 131(1): 115-25. [PubMed]

10. McDermott MM, Liu K, Criqui MH, Ruth K, Goff D, Saad MF, et al. Ankle-brachial index and subclinical cardiac and carotid disease: the multiethnic study of atherosclerosis. Am J Epidemiol. 2005 Jul;162(1):33-41. [CrossRef] [PubMed]

11. Newman AB, Shemanski L, Manolio TA, Cushman M, Mittelmark M, Polak JF, et al. Ankle-arm index as a predictor of cardiovascular disease and mortality in the cardiovascular health study. Arterioscler Thromb Vasc Biol. 1999 Mar;19(3):538-45. [PubMed]

12. Ганев ВС. Молекулно-генетична хетерогенност на предекспозицията към атеросклероза в България. [PhD Dissertation]. Medical University, 2003: Sofia: 68-70. (in Bulgarian).

13. Боев Т, Китова Л, Киров С, Ганев В. Генетична хетерогенност на LDLR ген при пациенти с хиперлипидемия и клинично манифестирана исхемична болест на сърцето. Българска Кардиология 1998: 4: 27-32. (in Bulgarian).

14. Хорварт АД. Молекулна хетерогенност на LDLR и АпоВ гените при здрави и пациенти с хиперхолестеролемия в България. [PhD Dissertation]. Medical University, 2001: Sofia 68-69. (in Bulgarian).

15. Mihaylov VA, Horvarth AD, Savov AS, Kurshelova EF, Paskaleva ID, Goudev AR, et al. Screening for spot mutations in the LDL receptor gene in Bulgarian patients with severe hypercholesterolemia. J Hum Genet 2004;

\section{Corresponding author:}

Lyudmila Georgieva Vladimirova-Kitova, $\mathrm{MD}, \mathrm{PhD}$

Clinic of Cardiology, University of Medicine, Plovdiv

2, Alexander Eksarch Str., Plovdiv 4000, Bulgaria

Tel: +359 32 652524, Fax: +35932602504

e-mail:kitov@vip.bg
49(4):173-176. [PubMed]

16. Владимирова-Китова Л, Бояджиева А. Глезен-ръка индекс при асимптомна изразена хиперхолестеролемия Българска Кардиология 2007;117-123. 32 (in Bulgarian)

17. Владимирова-Китова Л. Неинвазивни техники за оценка на атеросклерозата обзор Българска Кардиология 2006;12:12-20. 32 (in Bulgarian)

18. Станева МСт, Стайков Ив, Гадева Св, Карамфилов К, Димитров Н, Чирков Ал. Дебелина интима-медия на екстракраниалните каротидни артерии при болни с и без исхемична болест на сърцето. Диагностичен и терапевтичен ултразвук 2005;1:42-48. (in Bulgarian)

19. Станева МСт, Петров И, Карамфилов К, Димитров Н, Чирков Ал. Честота на екстракраниалната каротидна патология при болни с исхемична болест на сърцето. Българска кардиология 2006;1: 21-25. (in Bulgarian)

20. Vladimirova-Kitova L, Terzieva D, Marinov B. Intima-media thickness and flow-mediated vasodilation in asymptomatic subjects with newly detected severe hypercholesterolemia. Echocardiography 2009 Oct;26(9): 1060-1068. [CrossRef] [PubMed]

21. L. Vladimirova- Kitova, I. Manukov, R. Stefanov, F. Nikolov. Determination of intima- media thickness of the carotid artery by manual and automatic method. Bulgarian Journal of Cardiology 2006; 2:63- 68.

22. Simova I, Denchev S. Endothelial functional and structural impairment in patients with different degree of coronary artery disease development. Heart Vessels. 2008 Sep;23(5):305-15. [PubMed]

23. Mortality in treated heterozygous familial hypercholesterolaemia: implications for clinical management. Scientific Steering Committee on behalf of the Simon Broome Register Group. Atherosclerosis. 1999 Jan;142(1):105-12. [PubMed]. 